includes general lectures by Dr. R. Kronig (Delft) on the electronic structure of metals; Prof. L. Pauling (Pasadena) on valency in metals; Dr. H. B. G. Casimir (Eindhoven) or Prof. C. J. Gorter (Leyden) on superconductivity; Sir Lawrence Bragg (Cambridge) on slip in metals; Prof. N. F. Mott (Bristol) on work hardening and creep in metals ; H. Borelius (Stockholm) on transitions in super-cooled metallic solutions; A. Guinier (Paris) on precipitations in metals; Prof. W. G. Burgers (Delft) on crystal growth; Prof. J. H. van Vleck (Harvard) on fundamentals of ferromagnetism. The reception committee in Amsterdam is prepared to give advice and to make hotel reservations. Particulars of the conference can be obtained from Prof. C. J. Gorter, Kamerlingh Onnes Lab., Nieuwsteeg 18, Leyden.

\section{Summer School in Chemistry at Dublin}

A Sumcrer School in Chemistry is being arranged by the Irish Chemical Association and will be held in the Department of Chemistry, University College, Dublin, during July 5-9. Four courses of lectures will be given: "Some Recent Advances in Chemotherapy", by Dr. V. C. Barry, of the Medical Research Council of Ireland; "Recent Advances in the Determination of the Structure of Organic Compounds", by Prof. W. Cocker, professor of chemistry, Trinity College, Dublin; "Recent Advances in Biochemistry", by Prof. E. J. Conway, professor of biochemistry and pharmacology, University College, Dublin; "The Electronic Theory in Chemistry", by Prof. T. S. Wheeler, professor of chemistry, University College, Dublin. Particulars of the School can be obtained from the honorary secretary, Irish Chemical Association, The Laboratory, 12 Dawson Street, Dublin, to whom applications to attend must be sent not later than June 26.

\section{British National Committee for Crystallography}

THE Royal Society, as the national body adhering to the newly formed International Union of Crystallography, has recently set up a British National Committee for Crystallography under the chairmanship of Sir Lawrence Bragg. The members of the Committee are : Prof. W. T. Astbury, Prof. J. D. Bernal, Mrs. D. C. Hodgkin, Mrs. K. Lonsdale, Sir George Thomson, Prof. C. E. Tilley (all representing the Royal Society), Dr. G. M. Bennett (Chemical Society), Mr. D. A. Oliver (Institute of Metals), Prof. E. G. Cox (Institute of Physics), Dr. C. Sykes (Iron and Steel Institute), Dr. F. A. Bannister (Mineralogical Society), and Dr. H. Wilman (Physical Society). In addition to the above, Prof. P. P. Ewald, Dr. R. C. Evans and Dr. W. H. Taylor as members of the provisional executive committee of the International Union are ex officio members of the National Committee. The first General Assembly of the International Union of Crystallography is being held at Harvard University during July 28-August 3.

\section{Royal Society of Edinburgh: New Fellows}

THE following have been elected fellows of the Royal Society of Edinburgh : Sir Robert Allan, 41 N. Castle Street, Edinburgh 2; Prof. J. F. Allen, Department of Natural Philosophy, University of St. Andrews ; Mr. Alexander Cullen, architect and town planning consultant; Dr. F. J. Elliott, head of the Department of Physiology, Royal (Dick) Veterinary College, Edinburgh; Dr. M. A. Ellison, principal scientific officer, Royal Observatory, Edinburgh; Major M. D. W. Elphinstone, Threeways, Highfield
Road, Chislehurst, Kent ; Prof. T. H. Fraser, Department of Economics, Fouad I University, Cairo ; Sir John Fryer, secretary of the Agricultural Research Council ; Prof. T. N. George, Department of Geology, University of Glasgow; Dr. John Morrison Hay, deputy director and head of Engineering Division, Scottish Seaweed Research Association; Dr. J. F. Heggie, senior pathologist, North Middlesex County Hospital ; Dr. G. O. T. D. Henderson, officer-incharge, Oceanographic Laboratory, Leith; Dr. I. G. W. Hill, lecturer in pharmacology, University of Edinburgh; Dr. W. C. O. Hill, lecturer in physical anthropology, University of Edinburgh ; Prof. E. L. Hirst, Department of Organic Chemistry, University of Edinburgh; Mr. E. P. Hudson, director, Scottish Agricultural Industries, Ltd., Leith; Prof. W. Q. Kennedy, Department of Geology, University of Leeds; Mr. J. Gibson Kerr, 51 Castle Street, Edinburgh 2 ; Dr. D. N. Lawley, lecturer in statistics, University of Edinburgh; Dr. T. N. MacGregor, lecturer in gynæcological endocrinology, University of Edinburgh ; Dr. A. P. Orr, deputy director (senior principal scientific officer), Millport Laboratory, Scottish Marine Biological Association; Dr. R. Passmore, lecturer in clinical and industrial physiology, Department of Public Health and Social Medicine, University of Edinburgh; Dr. T. R. Tannahill, lecturer in astronomy, University of Glasgow ; Dr. S. I. Tomkeieff, lecturer in geology, King's College (University of Durham), Newcastle-upon-Tyne; Prof. C. H. Waddington, Department of Animal Genetics, University of Edinburgh, director of the Genetics Laboratory of the Animal Breeding and Genetics Research Organisation of the Agricultural Research Council.

\section{Announcements}

THE James Tait Black Memorial Prize of the University of Edinburgh for 1947, awarded for a biography or work of that character, has been awarded to Dr. C. E. Raven, regius professor of divinity in the University of Cambridge, and master of Christ's College, for his book "English Naturalists from Neckham to Ray" (see this issue of Nature, p. 373).

DR. J. E. KEyston, formerly assistant director of scientific research, Admiralty, has been awarded the United States Medal of Freedom with Bronze Palm for promoting interchange of scientific and engineering information and collaborating with American research groups during the Second World War. The investiture took place in Salisbury, Southern Rhodesia. Dr. Keyston has recently been appointed research secretary of the Central African Council (see Nature, February 14, p. 230).

The Committee of Privy Council for Medical Research has appointed Prof. H. P. Himsworth, professor of medicine in the University of London, to be a member of the Medical Research Council.

THE Council of the Royal Statistical Society offers the Frances Wood Memorial Prize, value $£ 30$, for competition in 1948. The Prize is offered for the best investigation, on statistical lines, of any problem bearing directly or indirectly upon the economic or social conditions of the people. Essays (which must be either printed or typed, and accompanied by copies of all statistical tabulations and diagrams) must be sent to the honorary secretaries of the Royal Statistical Society, 4 Portugal Street, W.C.2, not later than December 31, 1948. 